\title{
Tindak Tutur Ilokusi dalam Film Animasi Upin dan Ipin Episode "Seronoknya Wisata Air" serta Implikasinya terhadap Pendidikan Karakter Anak
}

\author{
Bini Lestari \\ SMKIT Smart Informatika Surakarta \\ Binilestari08@gmail.com
}

\begin{abstract}
This study aims to describe the forms of illocutionary speech acts in the animated film Upin \& Ipin in the series "Seronoknya Wisata Air". In addition, this study also describes the form of character education contained in the animated film. Furthermore, this study uses a qualitative method with a descriptive approach. The data source in this study obtained conversations in the animated film Upin \& Ipin obtained from Television. Data collection techniques in this study used the note taking technique, by noting every conversation that contains illocutionary speech acts. The data validity technique in this research is in the form of theory triangulation, data analysis using interactive analysis. The results of the study show that in the animated film Upin \& Ipin the series of "Water Tourism" contains illocutionary acts. For example assertive, directive and expressive. In this study, researchers also found the value of character education contained in the Upin \& Ipin animated film "Seronoknya Wisata Air", for example disciplinary value, creative value, value of achievement and friendly values.
\end{abstract}

Keywords: Illocutionary Speech Acts, Upin \& Ipin Animated Film, Character Education.

\section{Abstrak}

Penelitian ini bertujuan untuk mendeskripsikan tentang bentuk-bentuk tindak tutur ilokusi dalam film animasi Upin \& Ipin pada serial "Seronoknya Wisata Air". Selain itu, pada penelitian ini juga memaparkan bentuk pendidikan karakter yang terkandung dalam film animasi tersebut. Selanjutnya, penelitian ini menggunakan metode kualitatif dengan pendekatan deskriptif. Sumber data dalam penelitian ini diperoleh percakapan dalam film animasi Upin \& Ipin yang diperoleh dari Televisi. Teknik pengumpulan data dalam penelitian ini menggunakan teknik catat, dengan mencatat setiap percakapanpercakapan yang mengandung tindak tutur ilokusi. Teknik keabsahan data dalam penelitian ini berupa triangulasi teori, analisis data mengunakan analisis interaktif, Hasil penelitian menunjukkan bahwa dalam film animasi Upin \& Ipin serial "Seronoknya Wisata Air" ini mengandung tindak tutur ilokusi. Misalnya asertif, direktif dan ekspresif. Pada penelitian ini, peneliti juga menemukan nilai pendidikan karakter yang terkandung dalam film animasi Upin \& Ipin serial "Seronoknya Wisata Air", misalnya nilai displin, nilai kreatif, nilai menghargai prestasi dan nilai bersahabat.

Kata kunci: Tindak Tutur Ilokusi, Film Animasi Upin \& Ipin, Pendidikan Karakter. 


\section{PENDAHULUAN}

Perkembangan zaman melahirkan begitu banyak teknologi canggih dan tepat guna. Misalnya saja radio, televisi, handphone dan sebagainya. Teknologi ini, terlahir sebagai bentuk dari kemajuan zaman yang semakin pesat dan tentunya memiliki segudang manfaat. Teknologi ini tidak hanya terlahir begitu saja, akan tetapi teknologi ini juga berkembang mengikuti perkembangan zaman. Karena pada kenyataannya, semua teknologi dituntut untuk mengikuti arus perkembangan zaman yang ada, salah satunya yaitu televisi.

Televisi merupakan suatu teknologi canggih yang mampu menampilkan pesan suara dengan penampilan gambar di layar. Adanya televisi ini diawali dengan adanya radio, pada radio ini seseorang hanya dapat mendengarkan tanpa dapat melihat. Namun hadirnya televisi ternyata mampu menyita khalayak umum, sebab di dunia televisi seseorang dapat mendengarkan sekaligus melihat tayangan dari televisi. Hal ini senada dengan pendapat dari (Sari, Nariyah, \& Wihayati, 2019) yang mengatakan bahwa sejak kelahirannya, televisi telah berperan sebagai media massa yang menawarkan rangkaian citra dan bentuk-bentuk baru yang dipengaruhi dan memengaruhi terhadap kehidupan manusia. Berbicara tentang pengaruh bagi kehiduan, televisi ini memiliki pengaruh yang sangat kuat, baik itu dari segi positif maupun segi negatif.

Dilihat dari segi positif, tayangan televisi juga mampu menghadirkan bentuk-bentuk pendidikan yang dapat dikutip dan ditiru oleh penonton. Misalnya saja tayangan dakwah, tayangan pemberitaan, tayangan tayangan pendidikan dan masih banyak lagi. Akan tetapi, tidak hanya pengaruh positif yang muncul. Pada tayangan televisi ini juga memiliki sisi negatif, salah satunya yaitu tayangan yang ditampilkan tidak sesuai dengan umur penonton. Hal ini sering terjadi di lingkungan sekitar, banyak anak yang menonton sinetron atau FTV. Oleh karena itu, orang tua harus jeli dalam pengawasan, khususnya pengawasan dalam pemilihan tontonan yang berkualitas. Dalam penelitian yang dilakukan oleh (Kurnia \& Yeni, 2018) menunjukkan bahwa tontonan anak juga berpengaruh terhadap kualitas menulis siswa. Kurnia \& Yeni menggunakan pensil berkarakter animasi upin-ipin untuk merangsang kemampuan menulis anak. hasil yang didapatkan mengatakan bahwa terdapat pengaruh yang signifikan pada penggunaan media tersebut dengan kemampuan menulis anak.

Hal ini tidak luput dari orang tua yang memberikan tontonan animasi upin-ipin kepada anak-anak. Achsani (2019) mengatakan bahwa orang tua harus cermat memberikan tontonan kepada anak. Orang tua harus selalu memperhatikan pola perkembangan anak agar anak tidak salah dalam pergaulan. Pendapat ini diungkapkan dengan tujuan agar orang tua melek akan pendampingan dan pengawasan terhadap anak. Pasalnya, anak diusia kurang dari 10 tahun adalah masa perkembangan emas, mereka mampu meniru dan melakukan apa saja yang mereka lihat. Jika orang tua sampai terlena membiarkan anak berbuat sesuka hatinya (tidak dalam pengawasan) maka yang akan ditakutkan anak akan menjadi tipe pembangkang dan maunya sendiri.

Dunia pertelevisian mampu memikat masyarakat disegala usia. Karena, melalui televisi ini seseorang mampu mendapatkan sarana hiburan yang mereka sukai. Berbagai macam acara 
yang ditampilkan di televsisi ternyata mampu memikat hati masyarakat secara umum, sehingga mampu memunculkan nilai favorit pada hati nurani mereka. Berbicara tentang tayangan di televisi, era ini sangat banyak tayangan-tanyangan yang ditampilkan oleh berbagai chanel di televisi. Mulai dari tayangan untuk anak-anak hingga tayangan untuk orang dewasa, misalnya saja di Indosiar menampilkan ajang pencarian bakat seperti Dangdut Akademi, Global TV memiliki tayangan favorit seperti Super Deal 2 Milyar, Spongebob, Bedah Rumah dan masih banyak lagi.

Tidak mau ketinggalan dari channel lain, MNC TV pun juga memiliki tayangan tidak kalah seru yaitu Upin dan Ipin. Program tayangan ini tentunya menjadi program andalan di MNC TV, pasalnya film animasi ini sangat cocok untuk anak-anak disemua usia. (Yasa, 2019) mengatakan bahwa film animasi Upin Ipin mempromosikan budaya serta kehidupan masyarakat multikultur di Malaysia, Animasi upin ipin merupakan salah satu animasi yang ditayangkan di Negara Malaysia, yang mulai tayang pada tahun 2007 silam. Tayangan yang ditayangkan di TV9 Malaysia ini awalnya bertujuan untuk mendidik anak-anak dalam pembelajaran ilmu agama di bulan Ramadan, tetapi kini upin ipin telah mencapai 13 season yang mana dalam setiap episodenya berdurasi 5-7 menit. Di Indonesia sendiri tayangan upin ipin hampir di satu hari bisa ditayangkan selama 3 sampai 4 kali ppenayangan dan dengan durasi bisa lebih dari satu jam. Meskipun tayangan ini seringkali di ulang, namun dari penonton, khususnya anak-anak tidak pernah merasa bosan dengan tayangan tersebut. hal ini dikarenakan konflik yang diangkat dalam cerita tersebut mudah dipahami dan dicerna khususnya anak-anak.

Dari konflik yang mudah dicerna tersebut, menjadikan serial animasi upin ipin memiliki atau mengandung nilai pendidikan karakter yang dapat dipetik dan tentunya dapat ditiru oleh anak-anak. Pembiasaan penanaman pendidikan karakter sejak dini bagi anak-anak sangat efektif dan efisin agar kedepannya anak-anak mudah untuk mengenal kebaikan, mencintai kebaikan dan melakukan kebaikan. Hal ini sesuai pendapat Rosita \& Ferdian (2018) bahwa pendidikan karakter perlu ditanamkan sejak anak masih usia dini. Pendidikan karakter sendiri merupakan bentuk nilai yang ditanamkan pada anak-anak untuk menjadi manusia atau pribadi yang berakarter, sesuai dengan tabiat, moral dan nilai-nilai yang berlaku di masyarakat. Orang tua perlu menanamkan pendidikan karakter sangat penting untuk ditanamkan pada anak, agar sang anak menjadi seseorang yang berbudi pekerti.

Pada dasarnya pendidikan karakter memiliki beberapa beberapa pilar. Berdasarkan pilarpilar ini, beberapa ilmuan menjelaskan bahwa pilar-pilar tersebut dapat dijadikan sebagai pedoman atau patokan dalam mengukur pendidikan karakter seseorang. Menurut (Lickona, 2013: 40), pendidikan karakter mencakup tiga unsur pokok, yakni mengetahui kebaikan (knowing the good), mencintai kebaikan (desiring the good), dan melakukan kebaikan (doing the good). Sehingga sapat diartikan karakter yang baik adalah terdiri dari mengetahui hal yang baik, menginginkan hal yang baik, dan melakukan hal yang baik-kebiasaan dalam cara berpikir, kebiasaan dalam hati, dan kebiasaan dalam tindakan. Ketiga hal ini diperlukan untuk mengarahkan suatu kehidupan moral. 
Selain pendapat yang dikemukakan Lickona, terdapat pendapat lain mengenai komponenkompenen pendidikan karakter. Menurut Kemdiknas (Wibowo, 2013: 14), nilai-nilai luhur yang terkandung di dalam adat dan budaya suku bangsa telah melalui proses pengkajian dan perangkuman. Sebagai rumusan tujuan pendidikan nasional, Kemendiknas menyuntikkan nilainilai pendidikan karakter ini dalam kurikulum 2013. Terkait dengan upaya untuk mengembangkan materi kurikulum tentang pendidikan karakter, Pusat Kurikulum, Balitbang Diknas, telah merumuskan delapan belas pilar nilai karakter yang harus dikembangan untuk anak didik di Indonesia.

Penanaman pendidikan karakter melalui tayangan film animasi upin dan ipin tidak luput dari peran tindak tutur yang digunakan oleh tokoh-tokoh dalam animasi tersebut. salah satu bentuk tindak tutur yang dijumpai dari film animasi tersebut adalah tindak tutur perlokusi. Menurut Searle (dalam Wijana dan Rohmadi, 2009:21) tindak perlokusi adalah sebuah tuturan yang diutarakan oleh seseorang sering kali mempunyai daya pengaruh (perlocutionary force) atau efek bagi yang mendengarnya. Tindak ini disebut The Act of Affecting Somerthing Hal ini senada dengan pendapat yang diutarakan oleh Hestiyana (2018) dalam Jurnal Skriptorium yang mengatakan bahwa tindak tutur merupakan bagian terkecil dari sebuah komunikasi yang berasal dari sebuah kalimat, baik itu tuturan langsung ataupun tidak langsung. Dengan demikian, dapat disimpulkan bahwasannya tindak tutur adalah suatu ilmu bahasa yang mengkaji tentang bahasa dan keterkaitannya dengan lingkungan sekitar, dengan tindak tutur ini seseorang mampu memahami bahasa yang disampaikan penutur secara tersirat.

Berdasarkan teori yang dikemukakan, tindak tutur ini dibagi menjadi beberapa menurut kajiannya masing-masing, salah satunya yaitu tindak tutur perlokusi. Tidak berhenti disitu saja, Yule juga mengklasifikasikan tindak tutur perlokusi menjadi beberapa diantaranya yaitu tindak tutur (1) asertif yaitu sebuah ungkapan dalam pragmatik yang diungkapkan untuk menyatakan, menuntut, mengakui, menunjuk, melaporkan dan memberikan kesaksian. (2) Direktif, yaitu sebuah ungkapan yang terdiri dari meminta, mengajak, memaksa, menyarankan, mendesak, menyuruh, menagih, memerintah, dan memohon. (3) Ekspresif yaitu sebuah ungkapan yang biasa digunakan dalam bentuk berterimakasih, mengeluh, mengucapkan selamat, menyanjung, memuji, menyalahkan dan mengkritik. (4) Komisif, yaitu sebuah ungkapan yang biasa digunakan untuk mengungkap dalam bentuk besumpah, berjanji, mengancam, serta menyatakan kesanggupan dan (5) Deklaratif, yaitu sebuah ungkapan yang biasa digunakan untuk mengungkapkan mengesankan, memutuskan, membatalkan, melarang, mengabulkan, mengizinkan dan memaafkan (Yule, 2006).

Berdasarkan paparan tersebut, peneliti merasa tertarik untuk mengkaji lebih lanjut dari film animasi Upin dan Ipin yang ditayangkan di MNC TV. Peneliti tertarik untuk mengkaji film animasi tersebut dari segi pragmatik, yaitu pada segi tindak tutur sebagai pencipta nilai pendidikan karakter. Penelitian yang relevan dengan penelitian ini pernah dilakukan oleh Firmansah (2018). Dalam penelitian tersebut Firmansah mengungkapkan bahwa film animasi upin-dan ipin memiliki nilai-nilai spiritual seperti mempercayai adanya Tuhan melalui ciptaan- 
Nya serta menghargai diri sendiri, orang lain, dan lingkungan sekitar sebagai rasa syukur kepada Tuhan. Perbedaan penelitian ini terdapat pada kajian yang dilakukan. Pada penelitiannya, Firmansah mengkaji tentang nilai-nilai spiritual dalam film animasi upin-dan ipin. Sedangkan dalam penelitian ini mengkaji nilai-nilai pendidikan karakter pada film animasi upin-dan ipin. Hasil penelitian diharapkan dapat menambah pemahaman bagi masyarakat bahwa film animasi upin-dan ipin tidak hanya mengandung nilai-nilai spiritual, tetapi juga nilai-nilai pendidikan karakter.

Penelitian yang dilakukan oleh Hidayat \& Hamdani (2018) juga dapat dijadikan sebagai penelitian yang relevan dengan penelitian ini. Penelitian tersebut mengkaji bahwa animasi UpinIpin memiliki nilai-nilai toleransi beragama, seperti saling menghormati 2) saling menghargai, tidak menyalahkan kepercayaan orang lain, berbuat adil pada semua manusia meskipun berbeda agama. Dari penelitian tersebut dapat diketahui persamaannya yaitu sama-sama mengkaji tentang nilai pendidikan karakter. Bedanya, dalam peneltian ini akan mengkaji semua nilai-nilai pendidikan karakter sesuai dengan yang dikemukakan oleh kemendiknas, sedangkan pada penelitian tersebut hanya mendeskripsikan nilai pendidikan toleransi beragama.

\section{METODE PENELITIAN}

Penelitian dengan judul "Tindak Tutur Ilokusi dalam Film Animasi Upin dan Ipin Episode "Seronoknya Wisata Air" serta Implikasinya Terhadap Pendidikan Karakter Anak" tergolong dalam penelitian deskriptif kualitatif. Penelitian mengambil objek film animasi sebagai bahan dalam penelitian, selanjutnya penelitian ini juga disambungkan dengan pendidikan karakter pada anak. Metode penelitian ini dilakukan dengan cara deskriptif, yaitu mendeskripsikan data yang telah diperoleh dari penelitian. Teknik pengumpulan data dalam penelitian ini diambil secara simak dan catat, simak dilakukan dengan cara menyimak video film animasi upin ipin dan kemudian dilanjutkan dengan teknik mencatat data-data yang diperlukan dalam penelitian. Teknik ini dilakukan oleh peneliti secara berulang-ulang, dengan tujuan untuk mendapatkan data yang diinginkan dalam penelitian secara mendalam dan maksimal. Teknik analisis data yang digunakan dalam penelitian ini adalah metode interaktif.

\section{HASIL PENELITIAN}

\section{Bentuk Tindak Tutur dalam Film Animasi Upin \& Ipin}

Berdasarkan hasil penelitian yang telah dilakukan terhadap film animasi Upin \& Ipin The Series, ditemukan bentuk tindak tutur perlokusi yang meliputi asertif, direktif, ekspresif dan ekspresif. Berikut ini dipaparkan hasil penelitian sekaligus pembahasannya.

1. Asertif

Berdasarkan teori yang ada, tindak tutur asertif ini meliputi menyatakan, menuntut, mengakui, menunjukkan, melaporkan, dan memberikan kesaksian. Pada penelitian yang telah 
dilakukan terhadap film animasi Upin dan Ipin episode "Seronoknya Wisata Air" ditemukan beberapa kutipan percakapan yang mengandung ungkapan asertif, yaitu sebagai berikut.

a. Memberi Kesaksian

Pada penelitian terhadap Film Animasi Upin dan Ipin Episode "Seronoknya Wisata Air" ditemukan bentuk tindak tutur asertif dalam bentuk memberi kesaksian. Berikut ini disajikan kutipan percakapan yang mengandung asertif dalam bentuk memberi kesaksian.

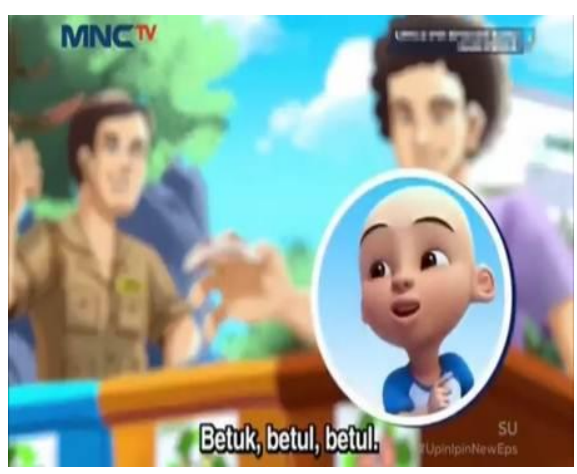

\section{Data 1}

Cikgu : :Sebelom masuk Cikgu nak jelasken beberapa peraturan yang harus diaati".

Penjaga : "Paling utame, kalian harus jaga kebersihan alam sekitar"

Upin : "Boleh bawa makanan masok?"

Penjaga : "Untok menjaga kebersihan, maka dilarang membawa masok makanan dalam bentuk apapun. Paham?"

serentak : "Paham!"

Cikgu : Pandai! Kita harus jaga kebersihan alam sekitar. (Pandai! Kita harus menjaga kebersihan alam sekitar kita).

Ipin : Betul.. betul.. betul

Upin : Cikgu bolehkan kite bagi makan dengan hewan tu? (Bu Guru, bolehkah kita membagi makanan pada hewan-hewan disini?)

Cikgu : Tak boleh. Dilarang bagi makan pada hewan sini, supaye menjaga kesehatan dan keselamatan hewan. (Tidak boleh. Dilarang memberi makanan pada hewan disini, untuk menjaga kesahatan dan keselamatan hewan).

Dilihat pada data 1 yang disajikan di atas, dapat dilihat dengan jelas bahwa pada kutipan data tersebut mengandung tindak tutur asertif memberikan kesaksian. Kata yang dicetak tebal dalam kutipan percakapan tersebut menjadikan penanda adanya tindak tutur asertif memberi kesaksian. Pada kalimat tersebut, kata Betul.. betul.. betul ini memberi 
kesaksian bahwasannya apa yang diungkapkan Ibu Guru (Cikgu) sebelumnya merupakan sebuah kebenaran. Dengan demikian, konteks tuturan yang terkandung dalam kutipan percakapan tersebut yaitu mitra tutur yang memberikan kesaksian atas pernyataan yang diungkapkan oleh penutur sebelumnya.

Selain data yang telah dipaparkan di atas, dalam penelitian yang dilakukan terhadap Film Animasi Upin dan Ipin ini juga menemukan data lain yang serupa. Data tersebut disajikan dalam paparan data 2 berikut ini.

Data 2

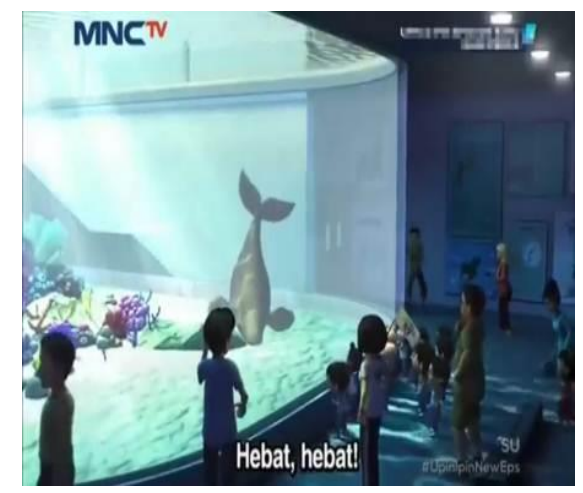

Upin : Kite kena cakap bahasa ikan. (Kita harus menggunakan bahasa Ikan untuk berkomunikasi).

Ipin : : Macem mana caranya? (Bagaimana caranya?)

Upin : (nana beu beu wue eu.. dengan menggunakan bahasa tubuhnya yang mirip dengan gerakan dugong).

Serentak : Ahahahah (Semuanya tertawa terbahak-bahak).

Jarjit : "Akhirnye dia nak cakap" (Akhirnya dia bicara juga).

Mei-mei : : "Wah comelnya!” (Wah. Lucunya).

Penjaga : : "Ya! Itulah bunyi dugong.

Jarjit : "Marvelous! Marvelous! (Hebat! Hebat!)

Pada kutipan data 2 yang dipaparkan, kutipan tersebut dapat diklasifikasikan dalam tindak tutur asertif memberikan kesaksian. Kata “"Marvelous! Marvelous! (Hebat! Hebat!)" yang diungkapkan Jarjit dalam percakapan tersebut merupakan bentuk kesaksian terhadap kalimat yang telah diungkapkan oleh mitra tutur sebelumnya. Dengan demikian, konteks tuturan yang terkandung dalam kutipan percakapan tersebut ialah pemberian kesaksian atas suatu kebenaran dari pernyataan yang diungkapkan oleh mitra tutur.

2. Direktif

Berdasarkan teori yang ada, ada beberapa pernyataan yang menjadikan pertanda terjadinya tindak tutur dirktif. Pernyataan tersebut terdiri dari meninta, mengajak, memaksa, menyarankan, mendesak, menyuruh, menagih, memerintah, mendesak dan memohon. Akan 
tetapi, tidak semua pernyataan yang ada tersebut dapat ditemukan dalam film animasi upin dan ipin. Adapun pernyataan yang ditemukan dalam film animasi upin dan ipin episode "Seronoknya Wisata Air" yaitu sebagai berikut.

a. Mengajak

Data 3

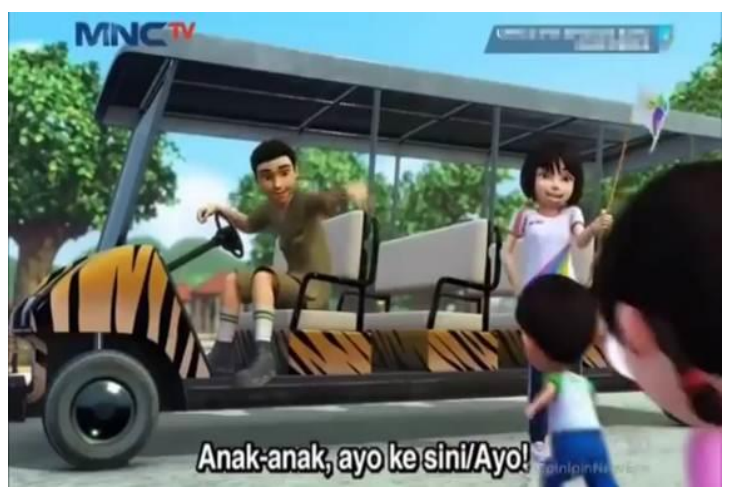

Pada penelitian yang dilakukan terhadap Film Animasi Upin dan Ipin Episode "Seronoknya Wisata Air" ditemukan bentuk tindak tutur direktif mengajak. Berikut ini akan dipaparkan data hasil temuan dari penelitian.
Upin
: “Tengok tu!” (Lihat itu!)
Cikgu
: "Murid-murid yo sinilah" (Anak-anak, ayo kemari).
Serentak : "Ayo"
Jarjit : "Wuow. Panjangnya leher jerapah tu. (Panjang sekali leher jerapah itu).

Data 3 yang disajikan di atas merupakan bentuk percakapan yang mengandung tindak tutur direktif mengajak. Bentuk tindak tutur ini biasanya digunakan untuk mengajak lawan tuturnya melakukan suatu pekerjaan. Pada data 1 yang disajikan di atas, terlihat Cikgu mengajak murid-muridnya untuk segera berjalan menyusulnya. Karena mobil yang akan mengantarkan mereka keliling kebun binatang sudah siap. Jadi, dapat disimpulkan bahwasannya dalam kutipan percakapan ini mengandung konteks mengajak, tepatnya mengajak murid-murid untuk segera berjalan kearah mobil.

Data 4 


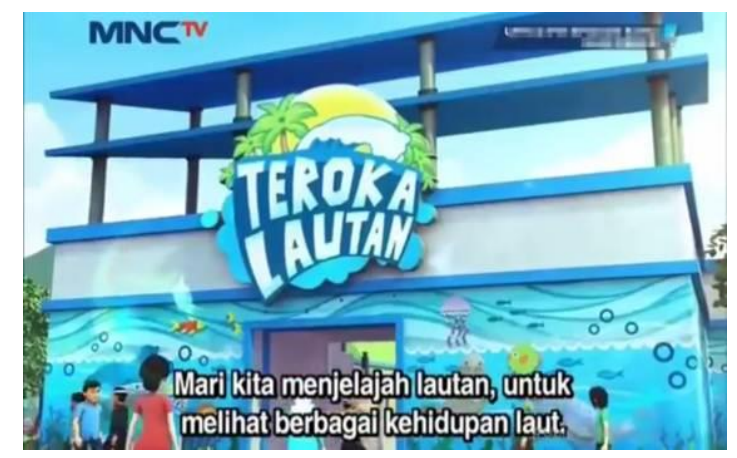

Cikgu : “Mari kite arungi lautan untok tengok pelbagai hewan di laot". (Mari kita menjelajah kehidupan laut, untuk melihat berbagai kehidupan laut).

Jarjit : "Tengok tu!" (Lihat itu!)

Serentak : :Dugong!"

Cikgu : "Yo, mari masuk"

Berdasarkan data 4 yang disajikan di atas, maka data tersebut dapat diklasifikasikan sebagai tindak tutur diretif dalam bentuk mengajak. Hal ini dapat dilihat pada kalimat yang dicetak tebal, yaitu “Mari kite arungi lautan untok tengok pelbagai hewan di laot” (Mari kita menjelajah kehidupan laut, untuk melihat berbagai kehidupan laut). Pada kalimat yang dicetak tebal tersebut, dapat dilihat dengan jelas bahwa Ibu Guru (Cikgu) mengajak anakanaknya untuk masuk ke wisata air melihat dunia hewan yang hidup di air. Dengan demikian, percakapan ini dapat digolongkan dalam tindak tutur direktif mengajak.

b. Menyuruh

Pada penelitian yang dilakukan terhadap Film Animasi Upin dan Ipin Episode "Seronoknya Wisata Air" ditemukan bentuk tindak tutur direktif menyuruh. Berikut ini akan dipaparkan data hasil temuan dari penelitian.

Data 5

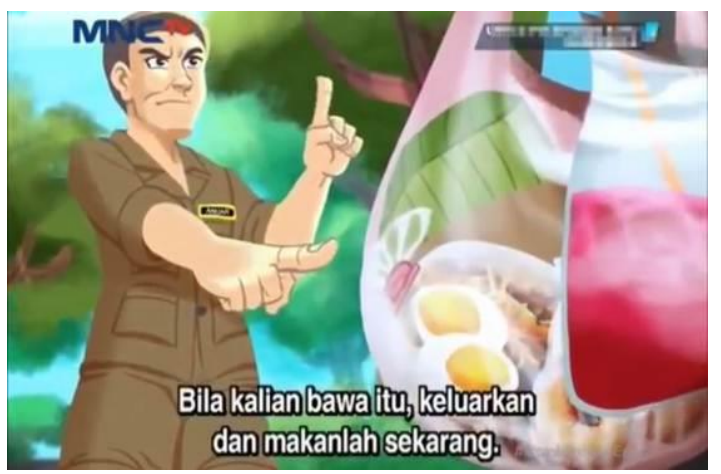

Cikgu : "Ingat ya, dilarang membawa makanan berat ke dalam" 

Penjaga : : "Seperti nasi goreng, lontong dan sejenisnya. Kalau kalian nak makan, makanlah sekarang"
Ehsan : :Makanan ringan tak boleh kah?"
Penjaga : "Boleh"
Cikgu : :Tapi jangan sekali-kali buang sampah tu semarangan. Kalian harus membuag sampah tu pada tempatnya.

Selain data 5 yang dipaparkan di atas, berikut ini juga dipaparkan bentuk tindak tutur direktif menyuruh. Lebih jelasnya lihat pada data 6 berikut ini.

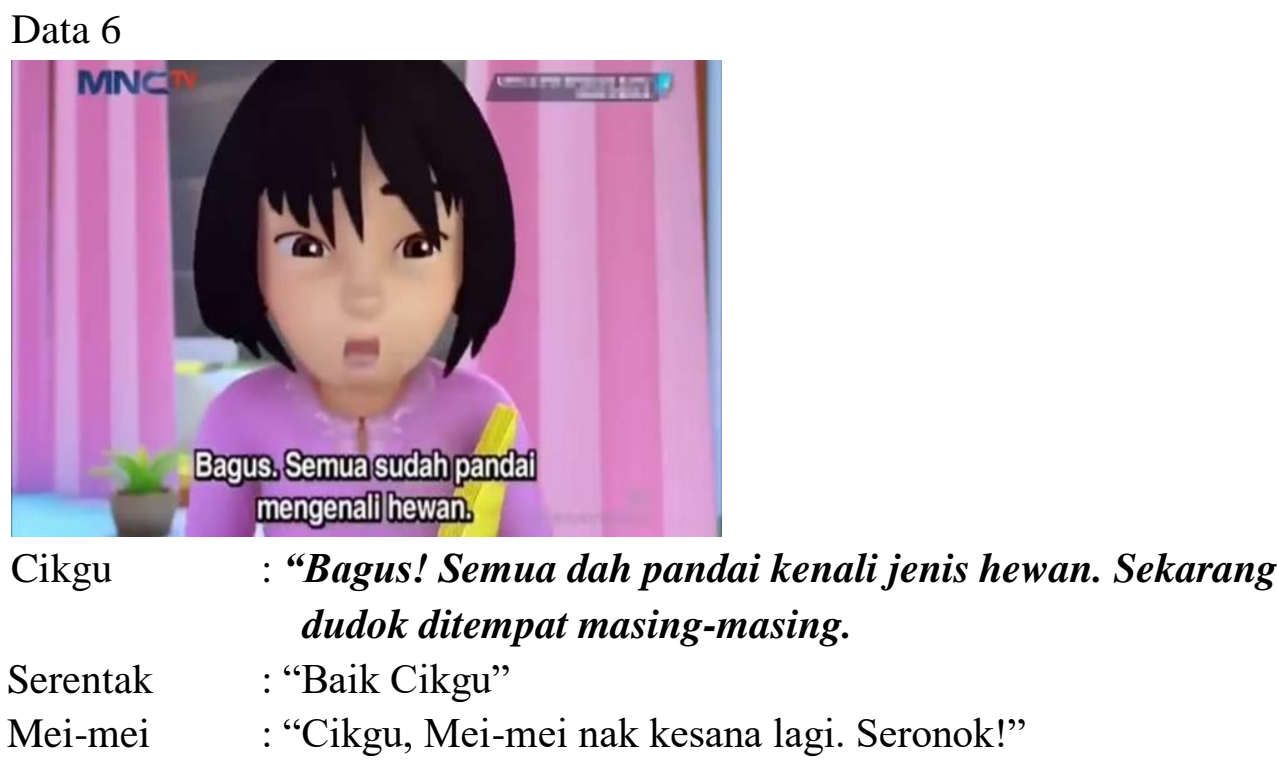

Melihat pada data 2 di atas, maka dapat diklasifikasikan dalam tindak tutur direktif bentuk menyuruh. Hal ini dapat dilihat pada kalimat yang dicetak tebal, yaitu pada kalimat "Bagus! Semua dah pandai kenali jenis hewan. Sekarang dudok ditempat masingmasing. Kalimat yang diungkapkan oleh Cikgu tersebut mengandung tuturan menyuruh. Dengan demikian, dapat dipastikan bahwa kalimat tersebut digologkan dalam bentuk direktif menyuruh

3. Ekspresif

Pada penelitian yang dilakukan terhadap film animasi Upin dan Ipin, ditemukan bentuk tindak tutur ekspresif. Menurut teori, tindak tutur ekspresif ini terdiri dari beberapa pernyataan yaitu terimakasih, mengeluh, mengucapkan selamat, menyanjung, memuji, menyalahkan dan mengkritik. Berdasarkan hasil penelitian, tidak semua pernyataan tersebut dapat ditemukan dalam film animasi Upin dan Ipin. Lebih jelasnya dapat dilihat pada paparan data berikut ini.

a. Berterimakasih

Data 7 


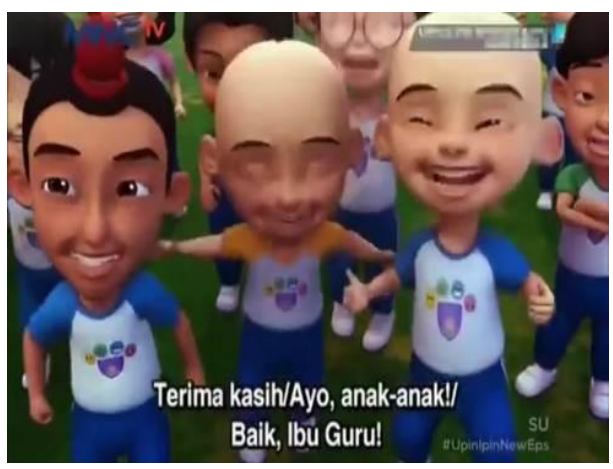

Penjaga : : Adik-adik, kenapa badak ni disebut badak sumbu?"

Ipin : :Sebab ia punya tandok dihidungnya"

Penjaga : : "Pandai, dan kerana sumbunya badak sumbu menjadi hewan yang pupos.

Mei-mei : "Haiya. Kenapa?"

Cikgu : "Karena dia diburu oleh manusie untuok didapatkan cula yang sangat berharga tu".

Penjaga : : "Betol! Jadi di kebun binatang ni semua hewan dilindungi, agar dia jangan pupos. Paham?"

Serentak : "Paham. Terimakasih.."

Berdasarkan percakapan yang dipaparkan di atas, maka data 2 dapat diklasifikasikan dalam tindak tutur ekspresif berterimakasih. Hal ini dapat dilihat dari percakapan yang dicetak tebal, yaitu "Paham. Terimakasih..". Jadi dapat dilihat dengan jelas bahwa kutipan percakapan tersebut dikelompokkan dalam tindak tutur ekspresif.

Data 8

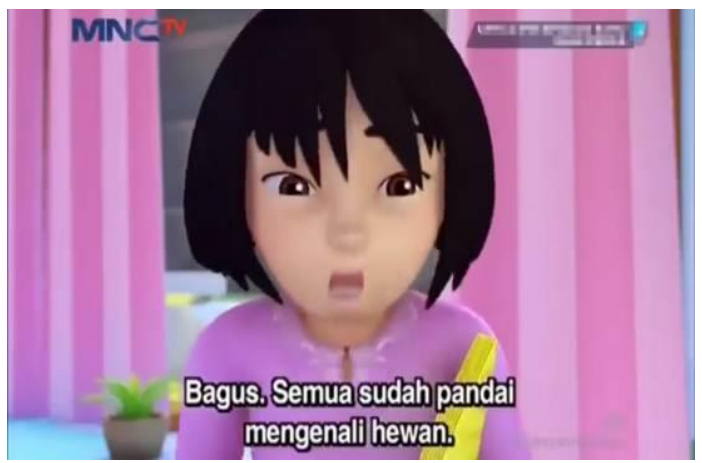

Cikgu : : "Bagus! Semua dah pandai kenali jenis hewan. Sekarang dudok ditempat masing-masing.

Serentak : "Baik Cikgu"

Mei-mei : : "Cikgu, Mei-mei nak kesana lagi. Seronok!"

Cikgu : "Boleh. Lain kali kita pergi melawat sambil belajar".

Serentak : "Yeyy. Terimakasih cikgu" 
Pada kutipan percakapan yang dipaparkan di atas, maka dapat diklasifikasikan dalam bentuk tindak tutur ekspresif. Hal ini dapat dilihat jelas dari kalimat yang dicetak tebal, yaitu "Yeyy. Terimakasih cikgu". Dengan demikian, data 2 dalam percakapan tersebut merupakan kelompok dari tindak tutur ekspresif berterimakasih.

\section{Implikasi Film Animasi Upin \& Ipin pada Pendidikan Karakter Anak}

Berdasarkan penelitian yang telah dilakukan terhadap Film Animasi Upin \& Ipin yang disandingkan dengan perkembangan anak usia 5-9 tahun, terbukti bahwa film animasi Upin \& Ipin ini memiliki keterlibatan yang sangat besar bagi perkembangan anak. Pasalnya Film ini menjadi film favorit di kalangan anak-anak, sehingga dapat dikatakan bahwasannya anak melakukan sikap imitasi (peniruan) dari film animasi Upin \& Ipin yang kemudian diterapkan dalam kehidupan sehari-hari. Hal ini sangat bagus adanya, sebab dalam film ini banyak mengandung pembelajaran, nilai moral dan pendidikan karakter yang dapat dipetik sekaligus diterapkan oleh anak.

Membentuk karakter seorang anak diperlukan beberapa proses untuk mencapai hasil yang baik, adapun proses ini dilakukan secara bertahap. Tahapan yang harus dilalui untuk mencapai hasil yang baik tersebut perlu adanya suatu proses yang berkesinambungan. Proses ini akan menjadikan suatu kebiasaan yang seterusnya menjadi karakter seseorang. Berbicara tentang pendidikan karakter, pada penelitian yang dilakukan terhadap film animasi Upin \& Ipin ini ditemukan banyak nilai pendidikan karakter yang dapat petik. Berikut ini dipaparkan bentuk pendidikan karakter yang ditemukan pada Film Animasi Upin \& Ipin serial "Seronoknya Wisata Air".

\section{Nilai disiplin}

Nilai kedisiplinan merupakan aspek yang sangat penting dalam pendidikan anak, ketika anak diminta untuk menyelesaikan tugas sesuai dengan instruksi yang diberikan. Nilai ini dapat dilihat dari data ke 4, ketika Cikgu meminta anak-anaknya untuk masuk dan melihat keindahan wisata dalam air. Secara serentak mereka tidak melakukan penolakan dan langsung mengerjakan apa yang diperintahkan, dengan serentak pula mereka langsung masuk ke wisata air tersebut. Secara teori, perilaku ini sudah menunjukkan nilai kedisiplinan dan mampu memberikan cerminan-cerminan kepada anak-anak yang menyaksikannya. Dengan demikian, Film Serial Upin \& Ipin ini terbukti mengandung pendidikan karakter yang sesuai dengan pilarnya.

\section{Nilai kreatif}

Pada dasarnya nilai kreatif dapat dibentuk oleh siapa saja. Nilai kekreatifan akan muncul secara otomatis pada pribadi anak. Misalnya saja pada data ke 2, ketika Upin, Ipin dan temantemannya menirukan suara dan perilaku dugong sehingga mengakibatkan dugong mengeluarkan suaranya. Dilihat dari kutipan ini, maka dapat disimpulkan bahwa Film Serial Upin \& Ipin mengandung pendidikan karakter berdasarkan pilar nilai kreatif. Dengan demikian, Film animasi ini sangat bagus dijadikan pembelajaran bagi anak-anak usia dini. 
Nilai menghargai prestasi

Nilai pendidikan karakter pada pilar menghargai prestasi memiliki makna yang hampir sama dengan mengapresiasi, yaitu ketika salah seorang memberikan tanggapan yang bersifat memuji kepada salah satu orang. Nilai menghargai prestasi ini muncul pada data ke 6, yaitu ketika cikgu mengapresiasi Ehsan yang sedang menirukan gerak-gerik hewan seperti halnya di Kebun Binatang. Sikap imitasi atau meniru yang dilakukan anak-anak ini tentunya memiliki nilai yang sangat bagus. Terutama ketika mereka melakukan peniruan terhadap sesuatu yang memiliki nilai kebaikan yang sangat tinggi. Dengan demikian, anak akan memiliki sikap yang sama seperti apa yang mereka lihat.

\section{Nilai bersahabat}

Nilai bersahabat lebih merujuk pada sikap persahabatan yang terjalin di dalamnya. Ketika satu sama lain saling bergotong royong melakukan suatu pekerjaan dan selalu menjaga tali pertemanan di antara mereke. Nilai sahabat ini tentunya juga dapat ditemukan di Film Animasi Upin \& Ipin Serial "Seronoknya Wisata Air". Pada serial ini, nilai bersahabat dapat dilihat pada data ke 8, yaitu ketika Upin, Ipin dan kawan-kawannya secara bersama-sama melakukan tebaktebakan dengan cara menirukan gerak gerik hewan dan secara serentak pula mereka menebaknya. Berdasarkan perilaku ini, maka dapat disimpulkan bahwasannya Film Animasi Upin \& Ipin ini mengandung pilar pendidikan pada nilai bersahabat.

\section{KESIMPULAN}

Berdasarkan pemaparan di atas, maka dapat disimpulkan bahwa dalam film animasi Upin \& Ipin banyak mengandung tindak tutur perlokusi, khsusunya pada bentuk asertif, direktif dan ekspresif. Pada bentuk asertif, peneliti menemukan bentuk ungkapan menduga dan menyatakan sebagai bentuk pertanda adanya tindak tutur asertif. Bentuk direktif, peneliti menemukan bentuk menyarankan, meminta dan memerintah dan bentuk ekspresif peneliti menemukan bentuk berterimakasih dan memuji. Pada tindak tutur yang ditemukan dalam film animasi Upin \& Ipin ini tentunya juga mengandung pendidikan karakter yang dapat dipetik sekaligus ditiru oleh anak didik, khususnya usia 6-9 tahun. Pendidikan karakter yang ditemukan dalam film animasi ini tentunya sesuai dengan pilar-pilar pendidikan karakter yang telah disampaikan dalam teori. Berdasarkan penelitian, peneliti menemukan empat pilar pendidikan dalam film animasi Upin \& Ipin serial "Seronoknya Wisata Air" yaitu nilai disiplin, nilai kreatif, nilai menghargai prestasi dan nilai bersahabat. Berdasarkan penelitian yang telah dilakukan, maka peneliti menyimpulkan bahwa film animasi Upin \& Ipin ini layak ditonton oleh anak usia dini. Pasalnya, selain film animasi tersebut bergenre anak-anak, film ini juga mengandung nilai pendidikan karakter yang dapat ditiru oleh anak-anak, dimana usia anak-anak merupakan usia emas dalam proses imitasi atau peniruan. 


\section{DAFTAR PUSTAKA}

Achsani, F. (2019). Aspek Moralitas dalam Anime Captain Tsubasa Melalui Penggunaan Tindak Tutur Asertif dan Ekspresif. Lingua, 15(1).

Firmansah, M. L. H. (2018). Memahami Nilai Spiritual dalam Film Upin-Ipin Sebagai Tayangan yang Layak Ditonton Anak Usia 2 - 6 Tahun. SELING : Jurnal Program Studi PGRA, 4(1), 51-67.

Hestiyana. (2018). Kesantunan Tindak Tutur Direktif pada Tuturan Anak dan Oranf Tua di Desa Ngumbul, Kabupaten Pacitan. Madah, 9(1), 101-116.

Hidayat, M., \& Hamdani, M. S. (2018). Representasi Toleransi Beragama Menurut Pandangan Islam Dalam Serial Animasi Upin Dan Ipin (Analisis Semiotika Episode Berjudul "Gong Xi Fa Cai” Dan "Dugaan Ramadhan”). Jurnal Ilmiah Mahasiswa FISIP Unsyiah, 3(2), 566579.

Kurnia, R., \& Yeni, S. (2018). Pengaruh Media Pensil Karakter Animasi Upin dan Ipin Terhadap Kemampuan Menulis Anak. JURNAL PENDIDIKAN USIA DINI, 12(2), 341-350.

Lickona, T. (2013). Mendidik untuk Membentuk Karakter (Bagaimana Sekolah dapat Memberikan Pendidikan Tentang Sikap Hormat dan Bertanggung Jawab). Jakarta: Bumi Aksara.

Rosita, F. Y., \& Ferdian, A. (2018). Pendidikan Karakter dalam Novel Cinta 2 Kodi Karya Asma Nadia. Alayasastra, 14(1), 55-71.

Sari, A. L., Nariyah, H., \& Wihayati, W. (2019). Studi Fenomenologi Film Animasi Upin dan Ipin di MNC TV dalam Membentuk Perilaku Imitasi pada Anak di TK Al-Muhibbin Kecamatan Sumber Kabupaten Cirebon. Signal, 7(1), 15-26.

Yasa, G. P. P. A. (2019). Animasi Si Uma: Representasi Lokalitas dan Budaya Bali. In Prosiding Seminar Nasional Desain dan Arsitektur (SENADA) (Vol. 2, pp. 333-339).

Yule, G. (2006). Pragmatik. Yogyakarta: Pustaka Pelajar. 